\title{
A CASE REPORT OF A CASE OF PERFORATING MOLE
}

Bratati Moitra $^{1}$

\section{HOW TO CITE THIS ARTICLE:}

Bratati Moitra. "A Case Report of a case of Perforating Mole". Journal of Evolution of Medical and Dental Sciences 2014; Vol. 3, Issue 08, February 24; Page: 2070-2072, DOI: 10.14260/jemds/2014/2104

INTRODUCTION: Molar pregnancy is a gestational trophoblastic disease. It is an abnormal condition of the placenta where there are partly degenerative \& partly proliferative changes in the young chorionic villi. Incidence varies from country to country. In India incidence is about 1:1601. It is common in patient with low dietary intake of animal fat, protein \& carotene. In 85\% cases karyotype is $46 \mathrm{XX}$, Molar chromosomes are derived entirely from father.

A patient presented in Gynae OPD on 11.02.13 with complains of pain lower abdomen for 3 months and history of spontaneous abortion of 3 months, 3 months back. Patient had 3 Dilatation \& Evacuation done from November, 2012 to February, 2013 in Purulia, West Bengal for irregular bleeding per vaginum. Her Last Menstrual Period was in August, 2012, she did not remember the exact date and she is para 1+2. First abortion was of 2 month 5 years back and then she had one Full Term Normal Delivery 4 years back. Baby is now alive and healthy. Third was again spontaneous abortion of three months, three months back.

On examination: Pallor was mild; Pulse - 98/minute B.P. - 100/60 mm of Hg, Chest - Bilateral vesicular breath sound was heard with no added sound. C.V.S. - S1 and S2 was heard.

On per abdominal examination: Uterus was 20 wks.in size with cystic to firm consistency mobile from side to side. On per Speculum Examination - Cervix was smooth and congested with discharge. Per Vaginal Examination - Cervix was long 50\% length was present. External Os was admitting tip to finger.

Report of investigations: Blood group was A+, $\mathrm{Hb}-10.6 \mathrm{gm} \%$, TC -6300 / cumm, Platelets -1.26 lakhs / ml, USG with color Doppler - Uterus was bulky $15 \times 7 \mathrm{~cm}$, with a large heterogeneous heteroechoic solid cystic lesson of $12 \times 4 \mathrm{~cm}$ in endometrial cavity - H. mole. Ovaries - both ovaries cystic, Rt - A cyst of size $2.5 \mathrm{~cm}$ diameter, Lt - A cyst of size $3 \mathrm{~cm}$ diameter, Serum BHCG - 4, 20, $300 / \mathrm{mIU} / \mathrm{ml}$ (11.02.13), SGPT - $11 \mathrm{IU} / \mathrm{Lt}$, SGOT - $35 \mathrm{IU} /$ Lt., Serum Bilirubin - $0.7 \mathrm{mg} / \mathrm{dl}$. Blood Urea - $14 \mathrm{ml} / \mathrm{dl}$, Serum TSH $-0.066 \mu \mathrm{IU} / \mathrm{ml}, \mathrm{FT} 3-1.56 \mathrm{pg} / \mathrm{ml}, \mathrm{FT} 4-1.31 \mathrm{ng} / \mathrm{dl}$.

Risk scoring was done - Risk score was 7 - which means she was in high risk category.

Patient was referred to oncologist. MAC regime was started. After $1^{\text {st }}$ cycle of chemotherapy

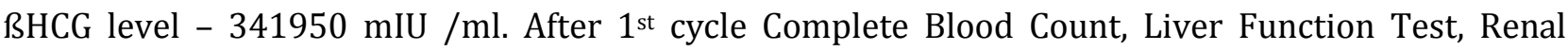
Function Test was repeated \& $2^{\text {nd }}$ cycle of chemo was started from 02.03.2013.

From $3^{\text {rd }}$ day of $2^{\text {nd }}$ cycle patient started complaining of pain lower abdomen. She became pale \& BP became 90/50 mm of Hg. Immediate fast I.V. R.L. drip was started \& requisition for blood was sent \& Blood Transfusion was started. Urgent USG \& CT scan was done. Perforation of uterus by molar tissue was found. Patient was prepared for emergency hysterectomy. On 06.03.13 emergency laparotomy was done. Blood was present in peritoneal cavity. There was fundal perforation of uterus near left cornu by molar tissue. Total abdominal hysterectomy was done. Both-theca lutin cysts were 
left as such2 units of Blood were given. On cutting open the uterus there was molar tissue with fluid filled spaces and old blood clots \& necrotic tissue filling the uterine cavity. Molar tissue had invaded myometrium\& perforated uterine fundus near left cornu. Post-operative period was uneventful. On Day 8 after surgery ßHCG was repeated. BHCG was $9800 \mathrm{mIU} / \mathrm{ml}$. Stitches were removed on $10^{\text {th }}$ day and patient was discharged on $12^{\text {th }}$ day with advice to report after 1 week. BHCG was repeated \& BHCG was $56.1 \mathrm{mIU} / \mathrm{ml}$. Opinion of oncologist was taken and it was decided to give another cycle of chemo. After chemo patient was discharged with advice to report after 1 month.

HPE report showed Chorio Carcinoma and BHCG on 13.05.13was $11.6 \mathrm{mIU} / \mathrm{ml}$. Patient was referred to Oncologist for further management.

DISCUSSION: About $15-20 \%$ of complete moles progress to persistent Gestational trophoblastic neoplasia ${ }^{2}$, there is a Plateau or re-elevation of HCG level. Post molar Gestational trophoblastic neoplasia may be benign or malignant. Staging of Gestational Trophoblastic neoplasia is ${ }^{3}$

Stage I - Disease confined to uterus.

Stage II - Gestational Trophoblastic neoplasia extending outside uterus but limited to genital structures.

Stage III - Gestational Trophoblastic neoplasia extending to lungs with or without genital tract involvement.

Stage IV - Metastasis to liver, brain, kidney \& gastrointestinal tracts.

A scoring system based on prognostic factors has been developed depending on age of patient, interval between end of antecedent pregnancy \& start of chemotherapy, Level of HCG, ABO group, size of largest tumor, site of metastasis, number of metastasis \& prior chemotherapy. If total score is more than 7 then it is kept in high risk category.

In this patient risk score was 7 . As the patient was in high risk category patient was referred to oncologist. Oncologist started combination chemotherapy with Methotrexate, actinomycin- D \& cyclophosphamide.

During the course of second cycle of chemotherapy patient developed sudden features of internal hemorrhage e.g. pain abdomen Tachycardia, fall of Blood Pressure, distension of abdomen. Urgent ultrasonography \& CT showed perforation of uterus with molar tissue. Emergency laparotomy was done and Total Abdominal hysterectomy with preservation of both theca lutin cyst was done. B-

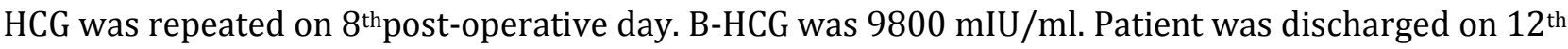
post-operative day with advice for follow up and patient was referred to oncologist.

\section{REFERENCES:}

1. Nousheen Aziz, Sajida Yousfani, Irfanullah Soomro, Firdous Mumtaz. Gestational Trophoblastic Disease. J Ayub Med Coll Abbottabad 2012;24(1)

2. John R. Lurain. Gestational trophoblastic disease I: epidemiology, pathology, clinical presentation and diagnosis of gestational trophoblasticdisease, and management of hydatidiform mole. AJOG Dec 2010.531-539

3. Smith HO, Kohorn E, Cole LA. Choriocarcinoma and gestational trophoblastic disease. Obstet Gynecol Clin North Am. Dec 2005;32(4):661-84. [Medline]. 


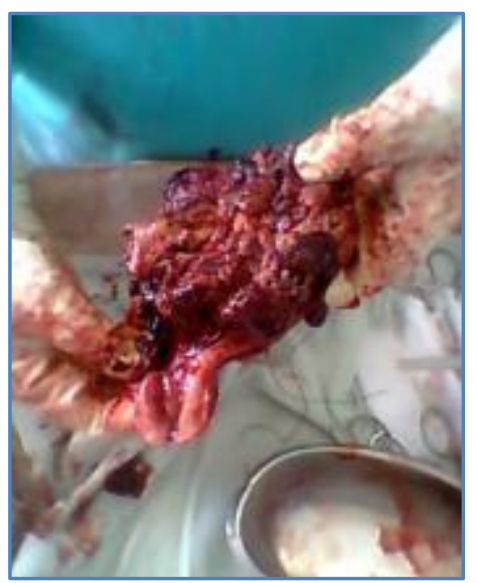

Uterine cavity with molar tissue

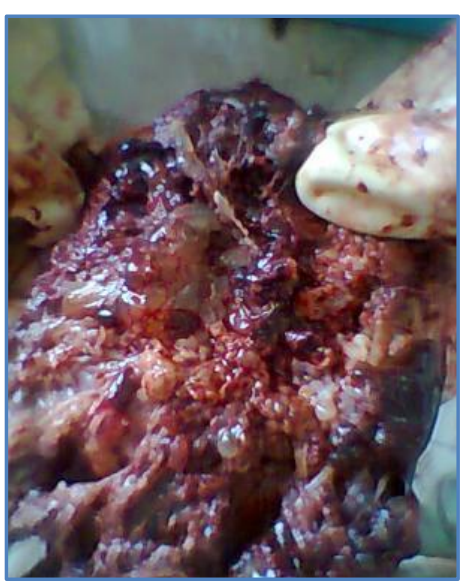

Uterine cavity with Molar Tissue

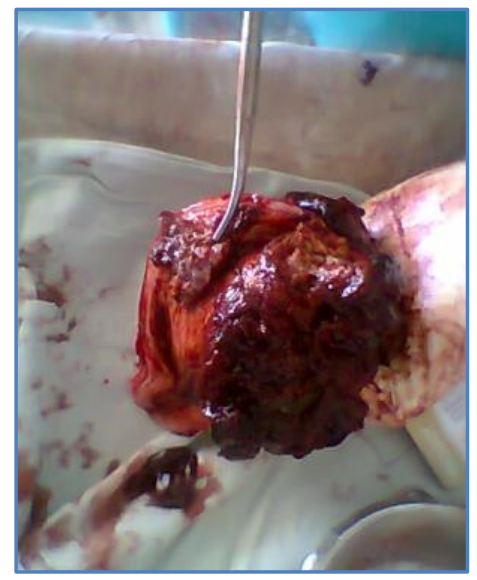

\section{Uterine cavity with Molar Tissue}

\section{AUTHORS:}

1. Bratati Moitra

\section{PARTICULARS OF CONTRIBUTORS:}

1. Assistant Professor, Department of Obstetrics \& Gynaecology, Rajendra Institute of Medical Sciences, Ranchi, Jharkhand.

\section{NAME ADDRESS EMAIL ID OF THE} CORRESPONDING AUTHOR:

Dr. Bratati Moitra,

24, Bardhawan Compound, P.0 - Lalpur, Ranchi - 834001, Jharkhand.

E-mail: bgs2104@yahoo.co.in

Date of Submission:22/01/2014. Date of Peer Review: 23/01/2014. Date of Acceptance: 03/02/2014. Date of Publishing: 24/02/2014. 